Joseph L. Sax

\title{
Legal Concepts of Cultural Heritage Property
}

PROPERTY Is ONE of the most intuitively natural of all legal concepts, as anyone who has watched two children contending over a toy can attest. It is also one of the most useful. Without it, there could be no bank accounts, no markets, no inheritance, and no security in one's home. Almost every material thing in life depends on the invention and elaboration of the idea and laws of property. The important qualifier is the term "almost." We all know that there are the obvious exceptions where ordinary proprietary rules do not and should not apply, such as in human slavery, or trade in children or human organs.

Though it is by no means as readily recognized by most people, the realm of cultural property is another misfit category. The most celebrated example is the case of the Parthenon Marbles, a large collection of marble sculptures removed from Athens in 1806 by Thomas Bruce, 7th Earl of Elgin, and deposited in the British Museum in 1816. It is obvious to almost everyone that no matter how compelling a legal case might be made for the proposition that ownership resides with the British Museum, this does not resolve the Greek repatriation claim. In cases such as this one, ownership alone cannot fully or adequately embrace the culturally freighted concept of "belonging." I discuss at length another such celebrated case, that of the Dead Sea Scrolls, in Playing Darts with a Rembrandt. ${ }^{1}$ Although the question of ownership in the usual sense was clear enough, the invocation of proprietary entitlement in this situation resulted in withholding crucial material from many of the most distinguished scholars of Biblical History for more than four decades. In matters such as these, the ordinary property system is just not sufficient to the task. Moreover-and this is a point I want to develop further-American law offers no alternative approach in such cases. At one level, the problem is easy enough to describe. It is simply that certain things evince a notion of entitlement that is in friction with conventional proprietary

1. Joseph L. Sax, Playing Darts with a Rembrandt: Public and Private Rights in Cultural Treasures (Ann Arbor: University of Michigan Press, 1999). 
notions - for example, that there should be open scholarly access to material of historical or scientific importance, notwithstanding the wishes of an owner.

Yet even when we understand the problem, it is not obvious how to resolve it. It is easy enough to agree that some things belong to a nation or a people, or that they belong to the ages. But that only suggests that we need somehow to move beyond the usual basic rules of ownership. One commonly hears major collectors of art make remarks like "I am only a temporary custodian of the great treasure I happen to own," but what does, or should, that mean operatively? For one thing, not every collector says it, or believes it; and art is, and has been since classical times, treated as a commodity, bought and sold by kings and popes, as well as commoners. Should there be a public right of access to great art? If so, how will such art be defined, of what will the right of access consist, and how should the law recognize such a right?

While it may seem obvious in retrospect that the Parthenon Marbles should not have been removed from Greece, why should Canova's Three Graces, an early 19th-century sculpture that was sold to a group of investors in the 1990s, not have been freely allowed to move from England to the United States when it was bought by the Getty Museum? True, it had been commissioned by the Duke of Bedford and stood in Woburn Abbey — itself a classified national treasure — and had been viewable by the public for nearly two centuries. Nevertheless, property law did not classify it as a fixture, and so legally it could be removed and sold by the Bedford estate. Under British law, local institutions were given an opportunity to equal the Getty's offer before an export license could be issued. As a result, the sculpture remained in Britain and is jointly owned and exhibited by the Victoria and Albert Museum and the National Galleries of Scotland. Does this case indicate that something is missing in our ordinary concept of private ownership if things are allowed to be freely sold to the highest bidder? Or is it that Britain is no longer as rich as it once was, and now has to turn to the law to limit the usual rule of the marketplace that would allow great works of art or historic manuscripts to be offered for sale by their owners, sometimes by their creators, and often by their heirs? With manuscripts, the problem is often one of restricted access, which can result from a family's desire to embargo for unduly long periods materials thought to be sensitive or embarrassing, or to limit access for an excessive time to a single researcher, usually an authorized biographer. I have discussed a number of these instances in Playing Darts with a Rembrandt, including such celebrated cases as the Freud papers at the Library of Congress, as well as lesser known examples involving the wish of prominent families to conceal evidence of homosexuality on the part of their noted and respected ancestors.

Competition for desired collections empowers owners to impose restrictions that the recipient institutions may neither want nor accept. Yet that, of course, is precisely the power granted by ordinary rules of property, along with the much-feared 
power of owners to feed embarrassing material to the fire if their wishes cannot be respected. Certainly there are situations where limited or delayed access is appropriate, such as when national security or attorney/client privileges are involved. Aside from these legitimate and sometimes perplexing problems, however, there is plainly a substantial range of disconnect between the legitimate interests of history and scholarship, and the ordinary rules of property.

Although resolution of these issues is problematic in many cases, and solutions are not usually as easy as just revising some rule of property (which some countries have done simply by vesting all antiquities in the state, or prohibiting all export), there are nevertheless some highly useful and productive steps that can be taken in various realms - some involving changes in law, but others that only involve changes in industry practice, or the norms of acceptable practice within a community.

I obviously cannot address all the possibilities here, whether relating to art, or manuscript collections, or antiquities (though I have tried to outline some of them in my writings ${ }^{2}$ ). Instead, I would like to make a more general point to illustrate how conceptions of private property can evolve to engage fruitfully with the challenges of heritage protection, as I think it is time for the United States to give more attention to the status of cultural property.

Let me begin with an illustrative example of where our law stands today. In 1990, on a ranch in South Dakota, a fossil hunter named Sue Hendrickson discovered an important paleontological relic, one of the largest and most intact Tyrannosaurus Rex fossils known. It was nicknamed "Dinosaur Sue" after its finder. But to whom did Sue belong? This was the question that ultimately reached a federal appeals court, which stated in its judgment on the case: "We hold that the fossil was land within the meaning of the statute.... It was a component part of the land, just like the soil, the rocks, and whatever other naturally occurring materials make up the earth of the ranch.... That the fossil once was a dinosaur which walked on the surface of the earth... [is] irrelevant." Therefore, the court said, the fossil was the property of the owner of the land, its legal status identical with that of a lump of coal that might be found there. ${ }^{3}$

For contrast, let me describe a most interesting French case that arose at about the same time, and which I have been following since its genesis nearly a dozen years ago (one aspect is still under French judicial review). My purpose is to illustrate how another country has revised its private property system to take account of, and to accommodate, public interest in the protection and preservation of cultural property.

2. See references in notes 1, 4, and 15; see also Joseph L. Sax, "Is Anyone Minding Stonehenge? The Origins of Cultural Property Protection in England," California Law Review, 78 (1990): 1543.

3. Black Hills Institute of Geological Research v. United States, 12 F.3d 737, 742 (8 Cir. 1993). 
On a weekend just before Christmas in 1994, three amateur speleologists led by Jean-Marie Chauvet were exploring the cliffs above the Ardèche River some forty miles northwest of Avignon. By chance they stumbled on the entrance to a completely intact cave that contained extensive, fabulous, and perfectly preserved cave drawings of lions, rhinoceroses, bison, mammoths, reindeer, and other animals. The artwork proved to be more than 30,000 years old.

The discovery sparked a series of legal and cultural questions: to whom did the cave drawings belong? Who had the right to take and disseminate photographs of the drawings? Should the cave be open to tourism, and, if so, who should benefit from that activity, and from the t-shirts and coffee mugs that would inevitably follow? What authority did the government have to protect the scientific and aesthetic resources in the cave? If the case had arisen in the United States, the answer to all these questions would have been simple: to follow what might be called the "lump of coal" rule, as exemplified by the Dinosaur Sue litigation.

Because there is a widely held view in America that France offers little respect for private property, it may come as a surprise to learn that the basic French law on these matters, found in Article 552 of the Civil Code and dating back to Napoleonic times, is identical to the American law explicated in the South Dakota case. Article 552 states that the owner of a tract of land also owns everything in the earth below it. It is not that the French are indifferent to property rights, but rather that American law has remained static on this point, while French law on cultural property has gradually evolved over a period of two centuries. The root property concepts of private ownership in France have been integrated into an ever-emerging public concept known as "patrimonial law." A French text on the subject describes the situation as follows: "We have passed from the basic idea of patrimony as familial, transmitted from one generation to the next, to a collective patrimony, witnessing the history of the nation. The whole French nation is responsible for its patrimony." ${ }^{4}$

The earliest notions of patrimonial property date back to 1810, when, under the French Empire, an effort was made to identify a list of important monuments that had escaped vandalism during the revolution. ${ }^{5}$ By 1887 , a wide range of public buildings were formally granted protection on the basis of their historical or artistic im-

4. Dominique Audrerie, La notion et la protection du patrimoine (Paris: Presses Universitaires de France, 1997), 15. I have loosely translated the text: "On est passé d’un patrimoine familiale, transmis de génération en génération, à un patrimoine collectif, témoin de l’histoire de la nation. La nation tout entière est responsable de son patrimoine."

5. For more information on the development of French cultural property law, see Dominique Audrerie, La notion et la protection du patrimoine; and Pierre-Laurent Frier, Droit du patrimoine cultural (Paris: Presses Universitaires de France, 1997). For the revolutionary beginnings of that history, see Joseph L. Sax, "Heritage Preservation as a Public Duty: The Abbé Grégoire and the Origins of an Idea," Michigan Law Review, 88:5 (1990): 1142. 
portance to the nation. ${ }^{6}$ In 1913, France enacted its first modern patrimonial law, authorizing the involuntary classification of private property as historic monuments. ${ }^{7}$ Then, in 1941, France enacted a law governing all private property that prohibited private archaeological excavations except with governmental approval and required any archaeological discoveries to be reported to the government. ${ }^{8}$ The government can take possession of the site for as long as five years. The purpose of this provision is to recognize the scientific value of such sites as a public resource and to make the preservation and advancement of scientific knowledge their preeminent value. Under this and similar patrimonial laws, private goals are subordinated to public ones. Yet private property interests are not simply swept aside. Indeed, a very interesting and important distinction is drawn. The owner of the property is indemnified for actual economic losses sustained during the period of scientific study (such as losses sustained by the delay in erecting a new building), but he does not own the scientific value of the site. The government has authority to take ownership of such sites under the power of eminent domain, but it is not obliged to do so.

With this very brief introduction to the structure of French cultural property law, I now return to the case of the Chauvet Cave. Once the cave was discovered, it was reported to the authorities, as required by the 1941 law. The government then closed the site to further exploration and began its own scientific investigations. It also exercised its eminent domain authority to make the cave a public property, as the government did not want it to be opened to tourist visits - a practice that had resulted in permanent damage to other ancient decorated caves, such as Lascaux. The expropriation of the cave raised the question of how much compensation the private owners of the overlying land were entitled to (putting aside the separate, though interesting, issue of what rights the discoverers themselves may have had). The stakes were huge. These were arguably the greatest and best preserved cave drawings ever discovered. The landowners asked for $\$ 150$ million, citing for comparison the tens of millions paid for a single Van Gogh painting and the revenues generated by the world's most famous tourist sites.

The original trial court decision in the Chauvet case limited the landowners' compensation to the very modest agricultural value of their tract. ${ }^{9}$ The court said there can be no compensation for historic or scientific value. It held that since the law of 1941 prohibited private archaeological excavations, the owners effectively had no private right to discover - and thereby to exploit - the value of the cave. The court seems to have been influenced by the fact that since the cave was undiscovered virtu-

6. Law of March 30, 1887.

7. Law of December 31, 1913, which Audrerie says (at p. 20) "met en place les grandes lignes of régime actuel" (which set in place the basic structure of the current law).

8. Law of September 27, 1941. The same year, on June 23, a law limited the exportation of works of art considered part of the national patrimony.

9. Tribunal de Grande Instance de Privas, Feb. 14, 1997. 
ally up to the time it was expropriated, the owners had not been deprived of anything from which they had previously benefited (or of which they were even aware).

Following several appeals, that decision was reversed, and the landowners were given a sizeable award (about $\$ 20$ million), reflecting the profits that tourism and the sale of images might have produced..$^{10}$ Even that court made clear, however, that the only values the owners could hold were those that were consistent with the state's patrimonial interests: they could not explore the cave themselves, they could not destroy anything in it, and they could not interfere with scientific work or charge for allowing it. That decision is still under appeal, and we do not yet know if the landowners will receive only the few thousand dollars they were originally awarded, or the $\$ 20$ million award.

But no matter how the Chauvet Cave case is ultimately resolved, it will not write the final chapter on the status of antiquities in France. In 2001, at the very time the appeal court was about to announce its decision, the legislature took over, and in effect adopted the original court's approach as the ruling legal principle. ${ }^{11}$ For archaeological relics that are fixtures on one's land, it abolished any presumption of ownership, in effect making the Civil Code provision inapplicable to antiquities that are part of the land.

In the French Senate debate, the government maintained that this change was not at odds with the principles that underlie the right of private property. For such objects, it was argued that "the maintenance of the current [rule]... is like a lottery in which the landowner profits while neither he nor his ancestors have either acquired or been handed down the archeological vestige included in their land.... [Any benefit he may receive is] due to the unpredictable acts of a third party [i.e., the finder, someone like Chauvet]. This is not in keeping with the rights of property that dictates one should be the owner of what one has acquired [through his own effort] or has been handed down." ${ }^{12}$ The new law was declared constitutional by the constitutional court and was duly enacted. ${ }^{13}$

I recount the history of the Chauvet cave case not as an ideal model to be used in all cultural property cases, but rather to demonstrate that a legal system founded

10. Court of Toulouse, Chamber of Expropriations, Mar. 26, 2001.

11. The legislative action was clearly motivated by the Chauvet case. In the Senate debate of October 5, 2000, one member expressly spoke of "the concern to avoid a new Chauvet case." "Si le souci d'éviter un nouveau cas Chauvet est legitime, la fréquence, très rare en réalite, de telles découvertes ne justifie pas de légiférer dans l'urgence.")

12. Senate, session of Oct. 5, 2000, remarks of M. Michel Duffour, secrétaire d'Etat ('D'ailleurs, l'injustice n'est-elle pas dans le maintien de la présomption actuelle, qui ressemble à une loterie dont profite le propriétaire alors que ni lui ni ses ancêtres n'ont acquis ni se sont vu transmettre le vestige archéologique compris dans leur terrain? Ce profit, dû à l'action aléatoire d'un tiers, n'est pas dans la logique la plus stricte du droit de propriété qui veut que l'on soit propriétaire de ce que l'on a acquis ou de ce que l'on s'est vu transmettre.").

13. The provision now appears as art. 18-1 in the law of Sept. 27, 1941, known as the law Carcopino. 
on conventional property notions, and that takes property rights seriously, can evolve in ways that protect the public interest in scientific and historical research and information, assure preservation of valuable artifacts, and promote public access to knowledge.

There is also a British law that promotes access to heritage properties, which, while dramatically different from the French law, is also very suggestive. The law permits the inheritors of objects that are recognized as having patrimonial value to indefinitely defer the payment of inheritance taxes if they agree to make the objects publicly accessible. "Inherited objects" include land and buildings, as well as works of art, furniture, silver, and the like. The "access" commitment may be met by lending the objects to museums or by allowing for visits to private residences or mutually agreed-upon sites. Owners who are concerned about security or privacy will usually arrange to have items brought to their solicitor's office for viewing, but others can be seen in private residences upon appointment.

All objects subject to these arrangements can be found online in the Tax-exempt Heritage Assets database, which can be searched by area, by artist, or by type of object. The database provides details about access, including contact information for making appointments to view the items, and the protocols to be followed if one encounters difficulty in arranging for access. ${ }^{14}$

There are also effective systems for protecting heritage properties that do not rely on formal changes in the law. A famous example was the great Art Treasures Exhibition of 1857, which took place in England a short time after the much more well-known Crystal Palace exhibition of 1851, the latter having essentially excluded works of art. The 1857 exhibition took place under the sponsorship of Prince Albert, at a time when almost all British art was still in private hands and Britain had fewer public museums than other European nations. Prince Albert wrote a remarkable invitational letter to Britain's great collectors, both aristocrats and industrial titans, urging that "a person who would not otherwise be inclined to part with a picture would probably shrink from refusing if he knew that his doing so tended to mar the realization of a great National object." ${ }^{15}$ Almost no one refused the Prince's importuning. The result was an exhibition consisting of several thousand extraordinary objects. Both the number and quality of the items loaned-many never before seen, almost all removed from their owners' premises for the first time-revealed the breathtaking richness of Britain's private collections: a rare

14. The Tax-exempt Heritage Assets database is administered by HM Revenue and Customs. It is available from http://www.hmrc.gov.uk/heritage.

15. Quoted in Joseph L. Sax, "Imaginatively Public: The English Experience of Art as Heritage Property,” Vanderbilt Journal of Transnational Law, 38 (Oct. 2005): 1097-1129. 
14th-century Coronation of the Virgin; ${ }^{16}$ forty-four works from the fabulous collection of the third Marquess of Hertford; thirty-five from Lord Spencer; eleven from the banker Baring, including a Mantegna, a Sebastiano del Piombo, and a Giorgione; two great Raphaels from Earl Cowper; ${ }^{17}$ and the list went on. The Art Treasures Exhibition, which was held in the industrial city of Manchester, was one of the most dramatic examples anywhere of the profound link between privilege and responsibility. It demonstrated that, during the previous century, while the aristocracy was feeling a bit besieged, a notion had evolved that the wealthy patrician class served a national purpose by its connoisseurship and collecting, and by its maintenance of historic buildings and sites. Insofar as such service was thought to justify its existence as a class, there inevitably followed the claim that the aristocracy should open privately owned but publicly important patrimony to the public. This concept was one element of what has come to be known as the "Victorian Compromise," and it helped to maintain political stability in Britain during a time of social upheaval and strife elsewhere.

Yet another technique for promoting openness of access, which I have discussed in Playing Darts with a Rembrandt, has particular application to libraries and museums: namely, standards and policies shared by institutions that are designed to reduce the effective power of owner-donors who seek inappropriately to embargo or delay access to materials of historical, scientific, or literary importance. I have observed that "libraries and museums probably underestimate the leverage they have over donors. It would surely be helpful if a donor who was shopping a collection around from institution to another were to find that the same limitations on unreasonable sequestrations and inappropriate exclusivities applied everywhere. ... [While inevitably] some things will be lost to gifts or even to destruction if extreme donor desires are not met ... libraries and museums would benefit by asking whether the time has come to adopt and enforce common policies on embargoes and access." 18

My purpose here has not been to insist on the rightness or wrongness of any particular approach to cultural heritage properties, whether by legal proscriptions, or tax incentives, or social influence. Rather, it has been to demonstrate that, if we are to take seriously the idea of protecting and providing public access to cultural heritage properties, something other than a rudimentary "lump of coal" approach to traditional property law and jurisprudence is both essential and possible.

16. Thought then to be by Giotto, since attributed to Maso di Banco, the most important of Giotto's followers, and now in the Fine Arts Museum of Budapest.

17. Both now in the National Gallery of Art in Washington, D.C.

18. Sax, Playing Darts with a Rembrandt, p. 199. 